\title{
PERLINDUNGAN HUKUM TERHADAP ANAK DI BAWAH UMUR YANG MENJADI KORBAN TINDAK PIDANA PENCABULAN
}

\author{
Darin Arif Mu'alifin ${ }^{1}$, Dwianto Jati Sumirat ${ }^{2}$ \\ 1. Institut Agama Islam Negeri (IAIN) Tulungagung \\ 2. Pengadilan Negeri Nganjuk \\ email: sumiratjati@gmail.com
}

\begin{abstract}
ABSTRAK
Tindak pidana pencabulan terhadap anak merupakan kejahatan yang melanggar moral, susila dan agama. Dampak tindak pidana ini terhadap anak adalah menimbulkan trauma fisik dan psikis terhadap korban terutama yang berusia anak-anak sehingga bisa berpengaruh pada perkembangan diri korban ketika dewasa nanti. Permasalahan dalam penelitian ini adalah: (1) Faktor-faktor apa yang mempengaruhi terjadinga tindak pidana pencabulan terhadap anak di bawah umur?, (2) Bagaimana upaya penanggulangan tindak pidana pencabulan terhadap anak di bawah umur? (3) Bagaimana perlindungan hukum bagi anak sebagai korban kejahatan tindak pidana pencabulan. Hasil penelitian dan pembahasan menunjukkan: Faktor-faktor yang dapat meningkatkan dan mempengaruhiterjadinya tindak pidana pencabulan terhadap anak di bawah umur yaitu: faktor rendahnya pendidikan dan ekonomi, faktorlingkungan atau tempat tinggal, faktor minuman (berakohol), faktorteknologi dan faktor peranan korban dalam ranah etiologi kriminologidapat di dikategorikan pada teori yang tidak berorientasi pada kelas sosial.Upaya untuk menanggulangi tindak pidana pencabulan terhadap anak di bawah umur dapat dilakukan dengan dua cara yaitu pencegahan dan penanggulangan jika tindak pidana pencabulan terhadap anak di bawah umur terlanjur terjadi.

Dalam konteks perlindungan terhadap korban kejahatan, adanya upaya preventif maupun revresif yang dilakukan, baik oleh masyarakat maupun pemerintah (melalui aparat penegak hukumnya), seperti pemberian perlindungan/pengawasan dari berbagai ancaman yang dapat membahayakan nyawa korban, pemberian bantuan medis, maupun hukum secara memadai, proses pemeriksaan dan peradilan yang fair terhadap pelaku kejahatan, pada dasarnya merupakan salah satu perwujudan dan perlindungan hak asasi manusia serta instrument penyeimbang. Dari sinilah dasar filosofis dibalik pentingnya korban kejahatan (keluarganya) memperoleh perlindungan.

Kata Kunci :Perlindungan Hukum, Anak, Tindak Pidana, Pencabulan.
\end{abstract}

\section{A. PENDAHULUAN}

Perlindungan korban tindak pidana dapat diartikan sebagai perlindungan untuk memperoleh jaminan hukum atas penderitaan atau kerugian pihak yang telah menjadi korban tindak pidana.1Segala sesuatu yang dapat meringankan penderitaan yang dialami seseorang akibat menjadi korban itulah yang dimaksud dengan perlindungan korban. Upaya untuk meringankan penderitaan tersebut dapat dilakukan dengan cara menegurangi penderitaan fisik dan penderitaan mental korban.

Di KUHP Indonesia, kejahatan dalam bentuk pencabulan ini diatur dalam pasal 289 KUHP. Pasal ini diatur dalam BUKU II BAB XIV tentang kejahatan terhadap kesusilaan. Anak yang berhadapan dengan hukum adalah anak yang terpaksa berkontak dengan sistem peradilan pidana karena:

1. Disangka, dinyatakan atau dinyatakan terbukti bersalah melanggar hukum.
2. Telah menjadi korban akibat perbuatan pelanggaran yang dilakukan orang/kelompok terhadapnya.

3. Telah melihat, mendengar, merasakan atau mengetahui suatu peristiwa pelanggaran hukum.

Dalam hukum positif, undang-undang yang mengatur masalah perlindungan saksi dan korban adalah Undang-Undang Negara Republik Indonesia No.31 Tahun 2014 tentang Perubahan Atas Undang-Undang Negara Republik Indonesia No. 13 Tahun 2006 tentang Perlindungan Saksi dan Korban. Namun, undang-undang tersebut belum secara keseluruhan membicarakan masalah bentukbentuk perlindungan korban sehingga harus dicari beberapa aturan lain dalam hukum positif yang medukung adanya bentuk perlindungan korban secara kongkrit. Diantaranya Undangundang Nomor 26 Tahun 2002 Tentang Hak Asasi Manusia serta beberapa aturan lainnya. 


\section{B. METODE PENELITIAN}

Penelitian yang dilakukan digunakan beberapa metode yang digunakan untuk mendapatkan hasil yang subyektif mungkin. Untuk mendapatkan hasil penelitian tersebut diperlukan informasi yang akurat yang mendukung. Sehubungan degan hak tersebut, metode yng digunakan dalam penelitian adalah sebagai berikut:

\section{Metode Pendekatan}

Metode pendekatan yang digunakan dalam penelitian ini adalah yuridis normatif yaitu penelitian hukum yang dilakukan dengan cara meneliti bahan pustaka atau data sekunder dengan melakukan inventarisasi hukum positif. Secara deduktif penelitian ini dimulai dengan menganalisis data sekunder dibidang hukum dapat dibedakan sebagai berikut:

a. Bahan Hukum Primer

Undang-Undang Dasar 1945, UndangUndang No 35 Tahun 2014 Perubahan Atas Undang-Undang 23 Tahun 2002 Tentang Perlindungan Anak, Undang-Undang Nomor 11 Tahun 2012 Tentang Sistem Peradilan Pidana Anak, Kitab UndangUndang Hukum Acara Pidana No 8 Tahun 1981, Undang-Undang 39 Tahun 1999 Tentang Hak Asasi Manusia.

b. Bahan Hukum Sekunder

Yaitu bahan-bahan yang erat hubungannya dengan bahan-bahan hukum primer yang dapat menunjang penulis Jurnal Ilmiah ini dapat membantu melengkapi bahan hukum primer, misalnya tulisan para ahli dan hasil para ilmuwan yang berbentuk makalah atau karya ilmiah.

c. Bahan Hukum Tersier

Yaitu bahan-bahan yang memberikan informasi tentang bahan hukum primer dan bahan hukum sekunder, misalnya Majalah, Koran, Internet dan Media-media lainnya.

\section{Spesifikasi Penelitian}

Spesifikasi penelitian yang digunakan adalah deskriptif analitis, yaitu menggambarkan dan menganalisis permasalahan berdasarkan peraturan Perundang-undangan.

\section{Teknik Pengumpulan Data}

Sesuai dengan tahap-tahap penelitian di atas, teknik pengumpulan data dilakukan dengan penelitian ke perpustakaan untuk mendapatkan data sekunder dan studi dokumen baik melalui media cetak maupun media elektronik.

\section{Metode Analisis}

Metode analisis data yang digunakan dalam penulisan Jurnal Ilmiah ini adalah dengan metode analisis normatif kualitatif.

\section{PEMBAHASAN}

\section{Faktor-Faktor Yang Mempengaruhi Terjadinya Tindak Pidana Pencabulan Terhadap Anak Di Bawah Umur.}

Dalam hal mengetahui faktor-faktor yang mempengaruhi terjadinya tindak pidana pencabulan terhadap anak di bawah umur, dapat dimulai dengan mengetahui peningkatan, hubungan pelaku sampai modus operandi dari kasus pencabulan terhadap anak di bawah umur, dalam hal ini Komisi Nasional Perlindungan Anak Indonesia yang berkaitan dengan masalah perlindungan anak, menentukan tiga jenis kekerasan terhadap anak yang diklasifikasikan sebagai kejahatan yang meresahkan anak dan mayarakat yang diantaranya ialah kekerasan fisik, kekerasan seksual dan kekerasan psikis.

Modus-modus operandi pencabulan terhadap anak di bawah umur diatas, ialah sejumlah modus operandi atau cara yang digunakan oleh pelakupencabulan demi mencapai kepuasan seksualnya yang dilampiaskan kepadaanak-anak. Dari beragam bentuk modus yang dilakukan oleh para pelakudisebabkan oleh suatu faktor yang mendukung perbuatan tersebut. Faktor penyebab tindak pidana pencabulan yang dimana memiliki motifberagam yaitu:

a. Pengaruh perkembangan teknologi

b. Pengaruh alkohol

c. Situasi (adanya kesempatan)

d. Peranan korban

e. Lingkungan:

1. Keluarga: broken home, kesibukan orang tua

2. Masyarakat

f. Tingkat pendidikan rendah

g. Pekerjaan (pengangguran)

h. Rasa ingin tahu (anak)

Faktor-faktor yang mempengaruhi terjadinya tindak pidana pencabulan terhadap anak di bawah umur ialah sebagai berikut:

1. Faktor Lingkungan

Faktor lingkungan merupakan salah satu faktor yang dapat mendukung terjadinya tindak pidana pencabulan terhadap anak di bawah umur.

2.Faktor Kebudayaan

Kebudayaan merupakan salah satu faktor yang dapat mempengaruhi terjadinya tindak 
pidana pencabulan terhadap anak di bawah umur yang dalam hubungannya dengan masalah ini merupakan suatu hasil karya yang diciptakan dan secara terus-menerus diperbaharui oleh sekelompok masyarakat tertentu atau dengan kata lain perkembangan suatu ciri khas masyarakat pada suatu daerah seperti gaya hidup manusia atau masyarakat.

3. Faktor Ekonomi

Dalam hal yang dimaksud tersebut ialah apabila seseorang mengalami himpitan atau kesusahan dalam bidang perekonomian, hal tersebut dapat menganggu akal pikirannya dan dapat mengakibatkan orang tersebut akan mengalami stres berat, sehingga dapat membuat orang tersebut dapat melakukan sesuatu hal yang tak bisa dikontrol oleh dirinya sendiri.

4. Faktor Media

Salah satu faktor yang turut serta mempengaruhi terjadinya tindak pidana pencabulan terhadap anak di bawah umur ialah faktor media.

5. Faktor Kejiwaan atau Psikologi.

Faktor kejiwaan dalam hal ini dapat mempengaruhi terjadinya tindak pidana pencabulan terhadap anak di bawah umur.

Pengaturan Tindak Pidana Pencabulan Terhadap Anak Di Bawah Umur Menurut Ketentuan Peraturan Perundang-undangan Yang Berlaku Di Indonesia.

Sebagaimana pengaturan bagi pelaku pencabulan terhadap anak di bawah umur menurut peraturan perundang-undangan yang berlaku di Indonesia ialah sebagai berikut :

1. Sanksi Pidana Bagi Pelaku Pencabulan Terhadap Anak Di Bawah Umur Menurut Kitab Undang-undang Hukum Pidana (KUHP). sebagai berikut :

a. Pada pasal 289 KUHP

Pengaturan pada pasal ini ialah apabila pelaku pencabualan terhadap anak di bawah umur melakukan pemenuhan hasrat seksualnya bukan dengan cara kekerasan atau ancaman kekerasan, melainkan dengan cara meminumkan suatu zat atau obat yang membuat korbannya pingsan atau tidak berdaya, pelaku dapat diancam dengan pidana penjara paling lama sembilan tahun.

b. Pasal 290 ayat (2) KUHP yang berbunyi :

1. Barang siapa melakukan perbuatan cabul dengan seseorang, padahal diketahuinya bahwa orang itu pingsan atau tidak berdaya.
2. Barang siapa melakukan perbuatan cabul dengan seorang, padahal diketahuinya atau sepatutnya harus diduganya, bahwa umurnya belum lima belas tahun atau kalau umurnya tidak jelas, yang bersangkutan belum waktunya untuk kawin.

3. Barangsiapa membujukseseorang yang diketahuinya atau sepatutnya diduganya, bahwa umurnya belum lima belas tahun atau kalau umumnya tidak jelas yang bersangkutan atau belum waktunya untuk dikawinin, untuk melakukan atau membiarkan dilakukan perbuatan cabul, atau bersetubuh diluar perkawinan dengan orang lain.

Perbuatan yang terjadi di sini adalah perbuatan pencabulan terhadap anak di bawah umur dilakukan dengan memaksakan kehendak dari orang dewasa terhadap anak di bawah umur yang dilakukan tanpa atau dengan kekerasan demi tercapainya pemenuhan hasrat seksual.

2. Sanksi Pidana Bagi Pelaku Pencabulan Terhadap Anak Di Bawah Umur Menurut Undang-Undang No 23 Tahun 2002 Tentang Perlindungan Anak.

Sanksi pidana bagi pelaku pencabulan terhadap anak di bawah umur menurut undang-undang perlindungan anak ialah sebagai berikut :

a. Pasal 82 ayat (1) yang berbunyi :

Setiap orang yang dengan sengaja melakukan kekerasan atau ancaman kekerasan, memaksa, melakukan tipu muslihat, serangkaian kebohongan, atau membujuk anak untuk melakukan atau membiarkan dilakukan perbuatan cabul, dipidana dengan pidana penjara paling lama 15 (lima belas) tahun dan paling singkat 3 (tiga) tahun dan denda paling banyak Rp. 300.000.000,00 (tiga ratus juta rupiah) dan paling sedikit $\mathrm{Rp}$. 60.000.000,00 (enam puluh rupiah).

\footnotetext{
Upaya Penanggulangan Tindak Pidana Pencabulan Terhadap Anak Di Bawah Umur

Upaya untuk menanggulangi tindak pidana pencabulan terhadap anak di bawah umur dapat dilakukan dengan dua cara yaitu pencegahan dan penanggulangan jika tindak pidana.pencabulan terhadap anak di bawah
} 
umur terlanjur terjadi, upaya tersebut dapat dilakukan yang antara lain sebagai berikut :

\section{Langkah-Langkah Pencegahan}

Anak harus mendapatkan perlindungan dari gangguan-gangguan berupa perlakuan salah kepada anak. Jika tidak dilindungi, maka anak sebagai generasi bangsa dapat mengalami kehancuran, lebih memperihatinkan apabila anak-anak sampai menjadi korban tindak pidana pencabulan, maka hancurlah kreativitas, kemauan, dan bakat seorang anak dalam mengembangkan pemikiran dan tumbuh kembang melalui proses coba-mencoba, sehingga generasi muda akan mengalami hambatan dan pada akhirnya secara keseluruhan akan menghambat berjalannya proses kaderisasi bangsa. Usaha-usaha yang dapat dilakukan oleh keluarga, masyarakat bersama pemerintah dan penegak hukum untuk mencegah terjadinya tindak pidana pencabulan terhadap anak di bawah umur ialah sebagai berikut :

a. Meningkatkan keamanan di lingkungan sekitar.

b. Membenahi sarana dan fasilitas di lingkungan sekitar, misalnya menambah atau memperbaiki penerang.

c. Perbaikan daerah-daerah yang relatif dengan tindak kejahatan khususnya pencabulan seperti rawa-rawa dan hutan disekitar lingkungan perumahan dikarenakan lingkungan seperti ini sangat potensial menimbulkan kriminalitas, termasuk tindak pidana pencabulan terhadap anak di bawah umur.

d. Pemberantasan film dan bacaan yang mengandung unsure pornografi yang beredar secara luas di kalangan masyarakat.

e. Partisipasi aktif atau keikutsertaan tokohtokoh agama dan masyarakat untuk membina dan menuntun masyarakat di lingkungan sekitarnya.

f. Masyarakat harus lebih intensif dalam menyikapi dan menyaring kebudayaan asing atau baru yang mengandung unsur negatif dan yang dapat merusak moral.

g. Dalam hal kehidupan rumah tangga atau keluarga, seperti hubungan orang tua dan anak selayaknya harus tetap efisien terjalin, seperti memberikan perhatian, nasehat, bimbingan dan perlindungan bagi anak demi kebaikannya dan menyelamatkannya dari perlakuan salah yang dilakukan oleh pelaku.

Dari rincian usaha mencegah terjadinya tindak pidana pencabulan terhadap anak di bawah umur di atas, merupakan suatu bentuk untuk mencegah agar perbuatan yang keji dan tidak bermoral yang korbannya ditujukan kepada anak-anak khususnya kasus pencabulan yang menimpa anak di bawah umur atau dengan kata lain mencegah lebih baik daripada menanggulangi. Mencegah perbuatan tersebut merupakan suatu bentuk untuk melindungi anak agar tidak menjadi korban tindak pidana. Perlindungan anak merupakan suatu usaha yang mengadakan suatu kondisi, dimana setiap anak dapat melaksanakan hak dan kewajibannya, maka dengan demikian kita wajib mengusahakan perlindungan anak sesuai dengan kemampuan untuk melindungi anak dari perlakuan salah yang ditujukan kepada anak, demi kepentingan tumbuh kembang anak serta kepentingan bangs dan Negara.

\section{Langkah-Langkah Penanggulangan Jika Terjadi Tindak Pidana Pencabulan Terhadap Anak Di Bawah Umur}

Terkadang hukuman bagi pelaku tidak sesuai dengan perbuatan pelaku tersebut. Langkah penanggulangan yang dapat menjadi acuan bagi masyarakat beserta pemerintah dan para penegak hukum dalam menanggulangi tindak pidana pencabulan terhadap anak di bawah umur ialah sebagai berikut :

a. Dukungan dari masyarakat.

b. Kepolisian sebagai penyidik dan sekaligus pelindung, pengayom dan pelayanan masyarakat khususnya dalam hal ini Unit Pelayanan Perempuan dan Anak (UPPA).

c. Penuntut umum adalah jaksa yang diberikan wewenang oleh undang-undang untuk melakukan penuntutan dan melaksanakan penetapan hakim"

sesuai dengan pasal 13 Kitab Undang-undang Hukum Acara Pidana (KUHAP).

d. Pihak kehakiman harus bekerja efisen dalam menjatuhkan hukuman yang benar-benar setimpaldengan perbuatan pelaku.

e. Lembaga independen dan lembaga swadaya masyarakat yang berkaitan dengan masalah perlindungan anak.

f. Media cetak maupun media elektonik.

Dari rincian di atas, merupakan suatu langkah-langkah yang bertujuan untuk menanggulangi tindak pidana pencabulan terhadap anak di bawah umur yang terbagi atas beberapa langkah yaitu langkah pencegahan dan langkah untuk menanggulangi jika terjadi tindak pidana pencabulan terhadap anak di bawah umur yang dapat dilakukan oleh keluarga, masyarakat beserta pemerintah. 


\section{KESIMPULAN}

Berdasarkan pembahasan diseluruh materi yang diuraikan mengenai permasalahan yang dikemukakan tentang Tindak Pidana Pencabulan terhadap anak dibawah umur, dapat diperoleh kesimpulan sebagai berikut:

1. Faktor-faktor yang dapat meningkatkan dan mempengaruhiterjadinya tindak pidana pencabulan terhadap anak di bawah umur yaitu: faktor rendahnya pendidikan dan ekonomi, faktorlingkungan atau tempat tinggal, faktor minuman (berakohol), faktorteknologi dan faktor peranan korban dalam ranah etiologi kriminologidapat di dikategorikan pada teori yang tidak berorientasi pada kelas sosial.

2. Upaya untuk menanggulangi tindak pidana pencabulan terhadap anak di bawah umur dapat dilakukan dengan dua cara yaitu pencegahan dan penanggulangan jika tindak pidana.pencabulan terhadap anak di bawah umur terlanjur terjadi.

3. Korban tindak pidana pencabulan selain mengalami penderitaan fisik juga mengalami penderitaan mental yang membutuhkan waktu lama untuk memulihkannya. Mengingat penderitaan yang dialami korban tindak pidana pencabulan tidak singkat untuk bisa memulihkan, maka aparat penegak hukum berkewajiban memberikan perlindungan terhadap korban tindak pidana pencabulan yang diimplementasikan dalam peraturan perundang-undangan sebagai produk hukum untuk memberikan keadilan bagi korban.

Dari sinilah dasar filosofis dibalik pentingnya korban kejahatan (keluarganya) memperoleh perlindungan.

\section{E. DAFTAR PUSTAKA}

Barda Nawawi Arief, Bunga Rampai Kebijakan Hukum Pidana, cet Pertama, (Bandung:Citra Aditya Bakti, 1996)

,Masalah Pegegakan Hukum dan Kebijakan Penanggulangan Kejahatan, (Bandung: PT. Citra Aditya, 2001)

Bambang Waluyo, Viktimologi Perlindungan Korban dan Saksi, Sinar Grafika, Jakarta, 2012
Edward Elgar, Indonesia, Undang-undang Pornografi, t.l.n No. 4928, ps. 1 ayat (4)

Koentjaraningrat, Pengantar Ilmu Antropologi, cet 8, (Jakarta: Rineka Cipta, 1990)

Muladi, Kapita Selekta Sistem Peradilan Pidana, Badan Penerbit Universitas Diponegoro, Semarang, 2012

P.A.Lamintang. Dasar-dasar Hukum Pidan Indonesia. (Bandung: Cita Aditya Bakti)

Romli Atmasasmita, Kapita selekta Hukum Pidana dan Kriminologi, (Bandung: Mandar Maju, 1995)

Soerjono Seokamto, Kitab Undang-undang Hukum Pidana, acara pidana, acara perdata, cet 1. (Jakarta : Visimedia, 2008)

Undang-Undang Dasar 1945

Undang-Undang No 35 Tahun 2014 Perubahan Atas Undang-Undang 23 Tahun 2002 Tentang Perlindungan Anak

Undang-Undang Nomor 11 Tahun 2012

Tentang Sistem Peradilan Pidana Anak

Kitab Undang-undang Hukum Pidana (KUHP)

Kitab Undang-Undang Hukum Acara Pidana No 8 Tahun 1981

Undang-Undang 39 Tahun 1999 Tentang Hak Asasi Manusia

Undang-undang No. 44 Tahun 2008 tentang Pornograf 